\title{
GROUNDWATER VULNERABILITY MAPPING IN MYSORE CITY USING GIS
}

\section{AND DRASTIC MODEL.}

\section{Lathamani $\mathbf{R}$}

Yuvaraja's college, University of Mysore. Corresponding author Email : lathamani17@rediffmail.com

\section{Abstract :}

The purpose of this study is to interpret the vulnerability zones of groundwater using the DRASTIC modeling method. The main objective of this model is to combine the results using DRASTIC algorithms and Geographical Information System (GIS), and to depict it as an effective method for groundwater pollution risk assessment. DRASTIC Model requires seven environmental parameters such as depth to water-level, net recharge, aquifer media, soil media, topography, impact of vadose zone and hydraulic conductivity of the area. All the parameters were integrated in the drastic model using GIS spatial analysis tools and techniques. The Groundwater Vulnerability Index of the active notes within the study is computed using GIS modeling methods. The Vulnerability index of the groundwater in this region ranges from $<70$ to $>100$. The outcome shows that, when the net recharge is high, the vulnerability is also found to be high. The GIS application of the DRASTIC model is found to be a suitable method for analyzing the groundwater vulnerability in Mysore city.

\section{Keywords:}

DRASTIC model, GIS, vulnerability index, Mysore city, groundwater pollution.

\section{Introduction:}

Groundwater makes up about twenty percent of the world's fresh water supply, which is about $0.61 \%$ of the entire world's water, including oceans and permanent ice. Global groundwater storage is roughly equal to the total amount of freshwater stored in the snow and ice pack, including the north and south poles. This makes it an important resource which can act as a natural storage that can buffer against shortages of surface water, as in during times of drought. (Richard, 2005). Day by day dependency on groundwater is increasing due to population growth. Human activities can negatively impact on water quality of groundwater, which may result in temporary or permanent loss of the resource, significant costs are required to remediate the aquifers and to remove the harmful materials from the water, prior to use. According to Al- 
Zabet 2002, vulnerability refers to the sensitivity of an aquifer system to deterioration due to an external action. In the last few decades, many techniques have been developed to assess groundwater vulnerability, including index, rating, hybrid, statistical and simulation methods (Voudouris, 2009). The DRASTIC method has been the most commonly used for mapping vulnerability in porous aquifers ( Aller et al., 1987). The aims of this study is to determine the aquifer vulnerability by integrating DRASTIC model into GIS, the hydrogeologic parameters were processed and mapped to delineate areas susceptible to contamination producing a risk assessment map of Mysore City. Study area Geographically, Mysore city is located between $12.18^{\circ}$ North latitude and $76.42^{\circ}$ East longitude with an altitude of 770 meters above Mean Sea Level. It is spread across an area of $128.42 \mathrm{~km} 2$ (50 sq mi) at the base of the Chamundi Hills in the southern region of Karnataka. The average annual rainfall is about $800 \mathrm{~mm}$. The topography of the Mysore city is characterized by a series of well-defined natural valleys which radiate from a ridge on high ground and fall gradually in all directions extending beyond the Mysore city corporation (MCC) and also in certain case even beyond Mysore Urban Development Authority (MUDA) boundary. The general slope of the city is from North to South. The general ground elevation of the city varies from both Northwest to Northeast portion (with the difference of $40 \mathrm{~m}$ ) and North to South (with the difference of $25 \mathrm{~m}$ ). The city comprises of ponds, ditches, low-lying areas and water bodies which serves as retention basins in reducing the flood intensity and controlling the flood damages during heavy rainfall. The types of soil found in this city are red soils (red gravelly loam soil, red gravelly clay soil, deep red clay soils), alluvial calcareous clay soils and alluvial clay soils. Main rock types are Igneous and metamorphic in origin. Some of the minerals found are kyanite, sillimanite, quartz, magnesite, chromite, soapstone, felsite, orundum, graphite, limestone, dolomite, siliconite and dunite. (Karnataka Municipal Reforms Cell, DMA, GoK). 


\section{Material and Method}

The DRASTIC model was adapted to find out the vulnerability of groundwater in Mysore city. To do the Drastic model seven parameters are necessary, such as depth to water, Net Recharge, Aquifer media, soil media, topography, impact of vadose zone and hydraulic conductivity. The data required for assessing the vulnerability of groundwater was retrieved from multiple sources. Spread sheet containing wells information located by using a Global Positioning System (GPS) was collected from Mines and Geology office, Mysore. Precipitation data was collected from the meteorological office. Soil layers map and slope (topography) map was collected from the Karnataka State Remote Sensing Applications Centre, Mysore. Geology map was collected from the Geological Survey of India (GSI) Bangalore. All data were converted when necessary, into spatial layers that were viewed and processed using Environmental Systems Research Institute's (ESRI) ArcGIS 9.1. The coding of each parameter was given based on Aller et al., 1987 method. The technique -inverse distance weightedll (IDW) interpolation in GIS was used to prepare the data for the entire city using sample points of net recharge and depth to water levels. The drastic formula was used in ArcGIS raster calculator to find out the vulnerability of ground water. The 100 meters spatial pixel resolution (raster Grid) raster layer was used for all raster manipulation in the work. HYDROGEOLOGIC FACTORS The hydrogeologic factors are described below: 1. Depth to Water (D) The depth to water is the distance, in feet, from the ground surface to the water table. It determines the depth of material through which a contaminant must travel before reaching the aquifer. In general, the deeper the water levels are, the longer the pollutant takes to reach the groundwater table (Voudouris \& Mandilaras, 2004). Twelve months (January to December) data (Table 1) for depth to water level measured in feet was used; the sample locations were created in the GIS environment using its appropriate latitude and longitude, then depth to water level as an input data, the IDW interpolation maps (Figure 1) was created for each month separately in hundred meter grid interval. Then 
these interpolated maps were re-coded based on formula's value for the analysis. 2. Net Recharge (R) Precipitation is the primary source of recharge, it infiltrates through the ground surface to the aquifer on an annual basis. Recharge is the principal vehicle for leaching and transporting contaminants to the water table. Leaching and transport of pollutants from the surface due to rainfall that infiltrates through the vadose zone is a very important associated process in terms of aquifer vulnerability. More recharge leads to greater chance for the contaminants to reach the water table. The grid layers (Figure 2) for net recharge were developed from the recharge data sets (Table 2). Recharge rates for the aquifers were usually derived from groundwater flow models and represent averages over large areas. All of the values in this study were in the ranges of $0-2$ to $10+$ inches per month. 3. Aquifer Media (A) Aquifer media refers to the consolidated or unconsolidated rock that serves as an aquifer.

Larger the grain size and more fractures or openings within the aquifer, results in higher permeability, and thus vulnerability, of the aquifer. The variable A (Aquifer media) was evaluated from the data retrieved from geological map (Figure 3). Based on this information, the aquifer media was classified. (Table3) 4. Soil Media (S): Soil media is the upper weathered zone of the earth, which averages a depth of six feet or less from the ground surface. Soil type plays an important role in the net recharge of an aquifer, with the presence of fine material decreasing infiltration and therefore also pollution potential. Soil media was evaluated from the map obtained from the Remote sensing application centre, Mysore (Figure 4). Based on Aller et al., 1987 method, the soils types were classified and values were assigned (Table 4). 5. Topography (T) Topography refers to the slope of the land surface. Topography helps to manage the likelihood that a pollutant will run off or remain long enough to infiltrate the ground surface. Where slopes are low, there is little runoff, and the potential for pollution is greater. Conversely, where slopes are steep, runoff capacity is high and the potential for pollution of groundwater is lower. Most of the slopes in this study were in the ranges of 0-2 and 2-6 percent. 6. Impact of 
the Vadose Zone Media (I) The vadose zone is the unsaturated zone above the water table. The characteristics of the vadose zone determines the time of travel of the contaminant through it and also the pathway and concentration of a pollutant, with the degree of attenuation related to the structure, mineral composition and organic matter content. The data for the variable I (vadose zone) was retrieved from National Bureau of Soil Survey Bangalore in the form of report and the information was converted into map (Figure 6).Values were assigned to the same (Table 6). 7. Hydraulic conductivity (C) Hydraulic conductivity refers to the rate at which water flows horizontally through an aquifer. As hydraulic conductivity increases, groundwater velocity as well as the speed at which pollutants are transported also increases, in turn rising in aquifer vulnerability. Conductivity values for the aquifers were usually derived from groundwater flow models and represent averages over large area. It is difficult to achieve an accurate estimation of hydraulic conductivity and it is also considered as a weakness of the DRASTIC method (Fritch et al., 2000; Stigter et al., 2006; Martinez-Bastida et al., 2010). The bedrock aquifers in this study comprise hydraulic conductivity values in the range of 1-700 gpd/ft. These values were assigned based on hydraulic conductivity of common rock types which is discussed ornately in open report - Guide to Permeability Indicesll by Lewis et al., 2006. Based on the hydraulic conductivity of the rock type's map (Figure 7) was created showing its respective values (Table 7)

\section{Result and Discussion}

The vulnerability maps obtained for twelve months evidenced the potential and sensitivity of the aquifers for contamination (Figure 8). Vulnerability ranges were categorized based on DRASTIC index values, less than 70 as very low, 70 - 80 low, 80 - 90 moderate, 90 - 100 high and more than 100 as very high. For the twelve months, February, May, July, August and November are having high vulnerability index mixed with moderate and low index values in some parts of the areas as shown in the maps. January, March, June, September and 
December are almost showing low vulnerability index with some parts having moderate and high index values, but April and October are showing very high vulnerability representing more than 100 index values. In the months of April and October groundwater level ranges 30 - 50 feet/month with rating 5 and index value 25. Net recharge of $10+\mathrm{mm} /$ month in April with rating 9 and index value 36 , October month is having 7 and $10+\mathrm{mm} / \mathrm{month}$ recharge in the high vulnerability area with 8 and 9 rating and 32 and 36 index values respectively. $70 \%$ of the high vulnerability area is covered with deep red clay soils, $10 \%$ alluvial clay soils, $10 \%$ alluvial calcareous clay soils and $10 \%$ red gravelly loam soils. Under aquifer media, Metabasalt constitute $70 \%$ of the high vulnerability area with $10 \%$ quartz mica schist/metapelites, $10 \%$ Ultramafics / Meta Ultramafics, 5\% Amphibolite/Horneblende Schist and 5\% Anorogenic younger granites. $60 \%$ of the high vulnerable area composes of $0-2 \%$ slope ranges, $38 \%$ of the area has $2-6 \%$ slope ranges and $2 \%$ of the land is having $6-$ $12 \%$ slope ranges all together constituting the topography of the high vulnerable area. Gravelly clay soils represent the vadose zone of the area. Hydraulic conductivity ranges from 1-700 m/day.

\section{Conclusion}

In order to assess the aquifer vulnerability for contamination potential, the combined use of the DRASTIC and geographical information system (GIS) demonstrated as an effective method for groundwater pollution risk assessment. DRASTIC index value was evaluated $<70$ to $>100$ for this study area. The main reason for very high vulnerability in the months of April and October is because of high net recharge $(10+\mathrm{mm})$ and $60 \%$ of the area is having $0-2 \%$ slope ranges. This slope percent allows water to precipitate more easily in to the soil. High net recharge correlates with the less sloped region. 


\section{Acknowledgement}

The authors would like to thank the assistance of the UGC for funding this major research project. We are thankful to all the government offices that have provided valuable information for the facilitation of the method used.

\section{Reference}

Al - Zabet, T. (2002): Evaluation of aquifer vulnetability of contamination potential using the DRASTIC method. Environmental Geology. vol 43: Pp. 203-208.

Aller, L., Bennet T., Lehr J. H., Petty R. J., and Hackett, G. (1987). -DRASTIC:

A Standardized System for Evaluating Ground Water Pollution Potential Using Hydrogeologic Settings.II US EPA Report 600/287/035, U.S. Environmental Protection Agency.

Fritch, T.G., Mcknight C.L., Yelderman J.C., and Arnold A.L. (2000). An aquifer vulnerability assessment of the Paluxy aquifer, central Texas, USA, using GIS and a modified DRASTIC approach. Environ. Management. vol 25:

Pp. 337-345.

Karnataka Municipal Reforms Cell, DMA, GoK, (2011). City sanitation paln, Mysore ,Karnataka.

Lewis, M. A., Cheney C. S., and Odochartaigh B. E., (2006). Guide to Permeability Indices .British Geological Survey Open Report, CR/06/160N.Pp. 29.

Martinez- Bastida, J.J., Arauzp M., and Valladolid M., (2010). Intrinsic and specific vulnerability of groundwater in central Spain: the risk of nitrate pollution. Hydrogeology Journal. vol 18; Pp. 681-698.

Greenburg, R. (2005). The Ocean Moon: Search for an Alien Biosphere. Springer Praxis Books. Runkel, A.C., Tipping, R.G., Alexander, E. C. Jr., Green, J.A., Mossler, J.H., and Alexander. 
Stigter, T.Y., Riberio L., and Carvalho Dill A.M.M.( 2006). Evaluation of an intrinsic and specific vulnerability assessment method in comparison with groundwater stalinization and nitrate contamination levels in two agricultural regions in the south Portugal. Hydrogeology Journal. vol 14: Pp. 79-99.

Voudouris, K.(2009). Assessing groundwater pollution risk in Sarigkiol basin, NW Greece. In: M. Gallo and M. Herrari (Eds) River Pollution Research Progress, Nova Science Publishers Inc. Chapter 7. Pp. 265-281.

Voudouris, K., and Mandilaras D.,( 2004). Evaluation of groundwater vulnerability using the DRASTIC method: Case study of alluvial aquifer of Glafkos basin, Achaia. Hydrotechnika. Journal of the Hellenic hydrotechnical Association. vol 14: Pp. 17-30 (in Greek).

\section{Tables}

Table 1

\begin{tabular}{|l|l|l|l|}
\hline Depth to Groundwater & \multicolumn{2}{|l|}{ Weight: 5} \\
\hline \multirow{2}{*}{ Months } & Ranges & Rating & Index \\
\hline \multirow{2}{*}{ January } & $30-50$ & 5 & 25 \\
\cline { 2 - 4 } & $15-30$ & 7 & 35 \\
\hline \multirow{4}{*}{ February and April } & $50-75$ & 3 & 15 \\
\cline { 2 - 4 } & $30-50$ & 5 & 25 \\
\cline { 2 - 5 } & $15-30$ & 7 & 35 \\
\hline \multirow{2}{*}{ March } & $50-75$ & 3 & 15 \\
\cline { 2 - 5 } \multirow{3}{*}{ October, November, and December. } & $30-50$ & 5 & 25 \\
\cline { 2 - 5 } & $50-75$ & 3 & 15 \\
\cline { 2 - 5 } & $30-50$ & 5 & 25 \\
\cline { 2 - 5 } & $15-30$ & 7 & 45 \\
\hline
\end{tabular}




\section{Table 2}

\begin{tabular}{|c|c|c|c|}
\hline \multirow[t]{2}{*}{ Net Recharge Months /month) } & \multicolumn{3}{|l|}{ Weight: 4} \\
\hline & Ranges (mm & Rating & Index \\
\hline January, February and March & $0-2$ & 1 & 4 \\
\hline April & $10+$ & 9 & 36 \\
\hline \multirow{2}{*}{ May } & $4-7$ & 6 & 24 \\
\hline & $7-10$ & 8 & 32 \\
\hline \multirow{2}{*}{ June } & $0-2$ & 1 & 4 \\
\hline & $2-4$ & 3 & 12 \\
\hline \multirow{4}{*}{ July and August } & $0-2$ & 1 & 4 \\
\hline & $2-4$ & 3 & 12 \\
\hline & $4-7$ & 6 & 24 \\
\hline & $7-10$ & 8 & 48 \\
\hline \multirow{2}{*}{ September } & $0-2$ & 1 & 4 \\
\hline & $2-4$ & 3 & 12 \\
\hline \multirow{2}{*}{ October } & $7-10$ & 8 & 32 \\
\hline & $10+$ & 9 & 36 \\
\hline \multirow{2}{*}{ November } & $4-7$ & 6 & 24 \\
\hline & $7-10$ & 8 & 32 \\
\hline December & $0-2$ & 1 & 4 \\
\hline
\end{tabular}

\section{Table 3}

\begin{tabular}{|l|l|l|}
\hline Aquifer Media & Weight: 3 \\
\hline Aquifer & Rating & Index \\
\hline Quartz mica schist/metapelites and carbonates & 9 & 27 \\
\hline Amphibolite/ hornblende schist with crystalline limestone & 8 & 24 \\
\hline Medium grained, grey adamellite and granodiorite & 7 & 21 \\
\hline Anorogenic younger granites & 6 & 18 \\
\hline Fuchsite quartzite with kyonite & 5 & 15 \\
\hline Metabasalt & 4 & 12 \\
\hline Ultramafics and meta Ultramafics & 3 & 9 \\
\hline Charnockite & 2 & 6 \\
\hline Dolerite & 1 & 3 \\
\hline
\end{tabular}


Table 4

\begin{tabular}{|l|l|l|}
\hline Soil Media & \multicolumn{2}{|l|}{ Weight: 2} \\
\hline Soil types & Rating & Index \\
\hline Red gravelly loam soils & 5 & 10 \\
\hline Red gravelly clay soils / Gravelly clay soils & 4 & 8 \\
\hline Alluvial calcareous clay soils & 3 & 6 \\
\hline Alluvial clay soils & 2 & 4 \\
\hline Deep red clay soils & 1 & 2 \\
\hline
\end{tabular}

\begin{tabular}{|c|c|c|}
\hline \multicolumn{3}{|l|}{ Table 5} \\
\hline \multirow{2}{*}{$\begin{array}{l}\text { Topography } \\
\text { Slope Ranges (\%) }\end{array}$} & \multicolumn{2}{|c|}{ Weight: 1} \\
\hline & Rating & Index \\
\hline $0-2$ & 10 & 10 \\
\hline $2-6$ & 9 & 9 \\
\hline $6-12$ & 5 & 5 \\
\hline $12-18$ & 3 & 3 \\
\hline
\end{tabular}

\begin{tabular}{|l|l|l|}
\hline \multicolumn{2}{|l|}{ Table 6} \\
\hline \multirow{2}{*}{$\begin{array}{l}\text { Impact of Vadose } \\
\text { zone Ranges }\end{array}$} & Weight: 5 \\
\cline { 2 - 3 } & Rating & Index \\
\hline Gravelly clay soils & 3 & 15 \\
\hline Clayey loamy soils & 2 & 10 \\
\hline & & \\
\hline
\end{tabular}

Table 7

\begin{tabular}{|l|l|l|}
\hline Hydraulic Conductivity & \multicolumn{2}{|l|}{ Weight: 3 } \\
\hline Ranges (m/ day) & Rating & Index \\
\hline $300-700$ & 4 & 12 \\
\hline $300-700$ & 4 & 12 \\
\hline $100-300$ & 2 & 6 \\
\hline $100-300$ & 2 & 6 \\
\hline $100-300$ & 2 & 6 \\
\hline $1-100$ & 1 & 3 \\
\hline $1-100$ & 1 & 3 \\
\hline $1-100$ & 1 & 3 \\
\hline $1-100$ & 1 & 3 \\
\hline
\end{tabular}


Figure 2

A Four Monthly Peer Reviewed Journal VISHWASHANTI MULTIPURPOSE SOCIETY 


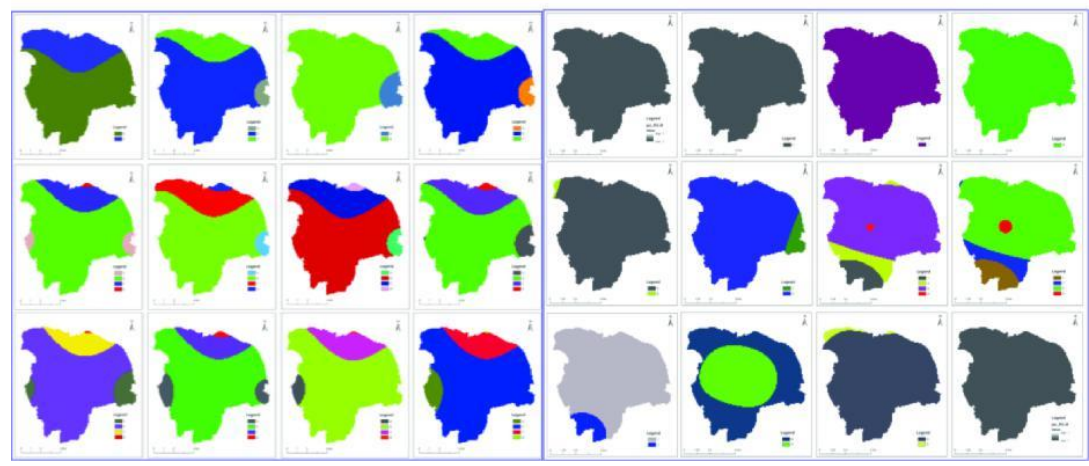

Figure 3

Figure 4
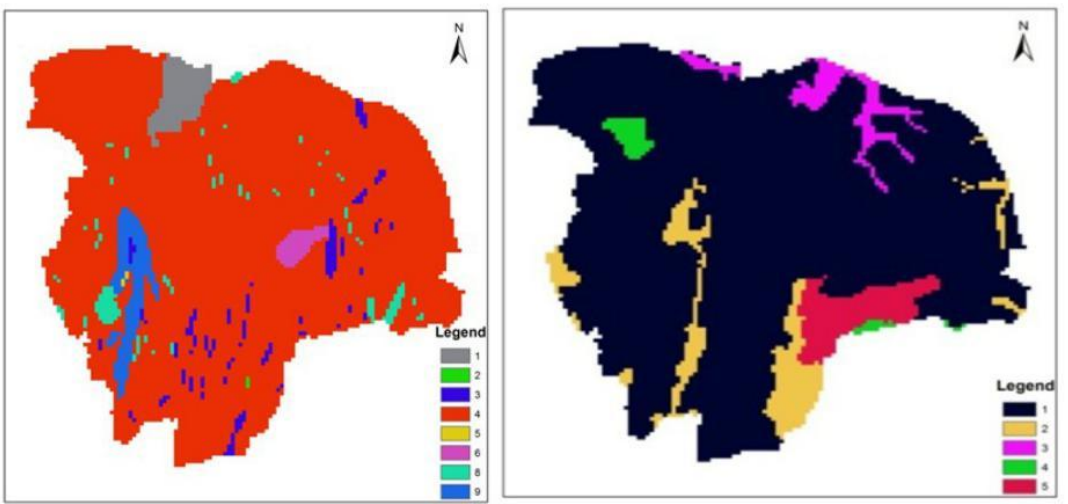

Figure 5

Figure 6
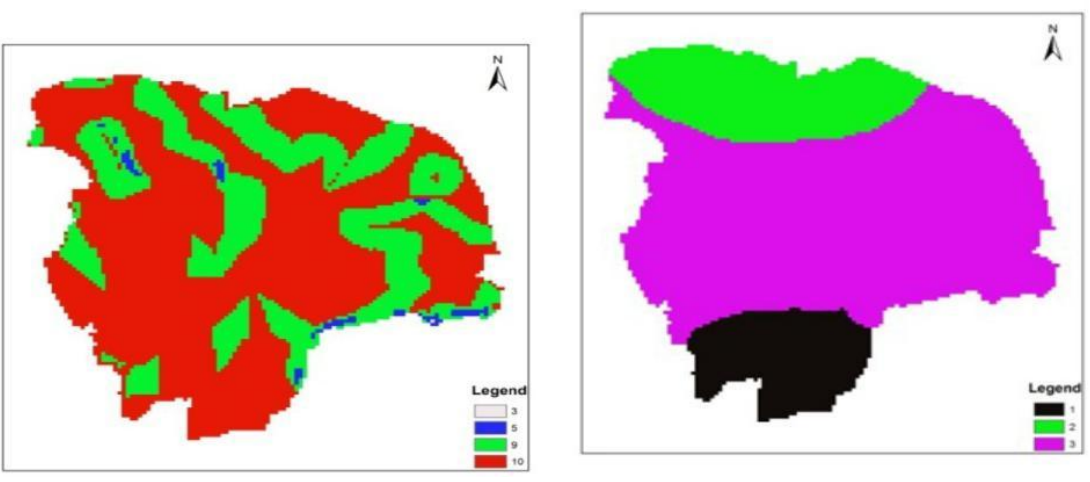
Figure 7

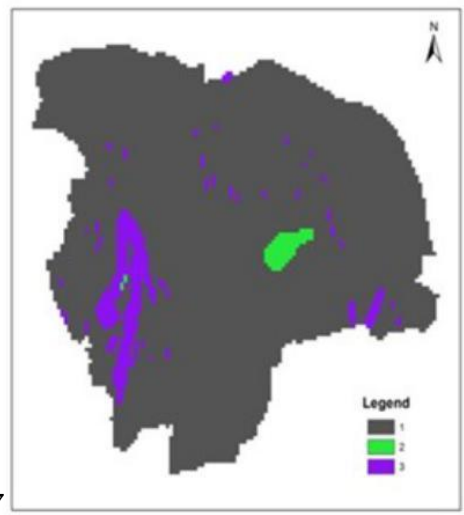

Figure 8

VuInerability Map of Mysore City - 2011

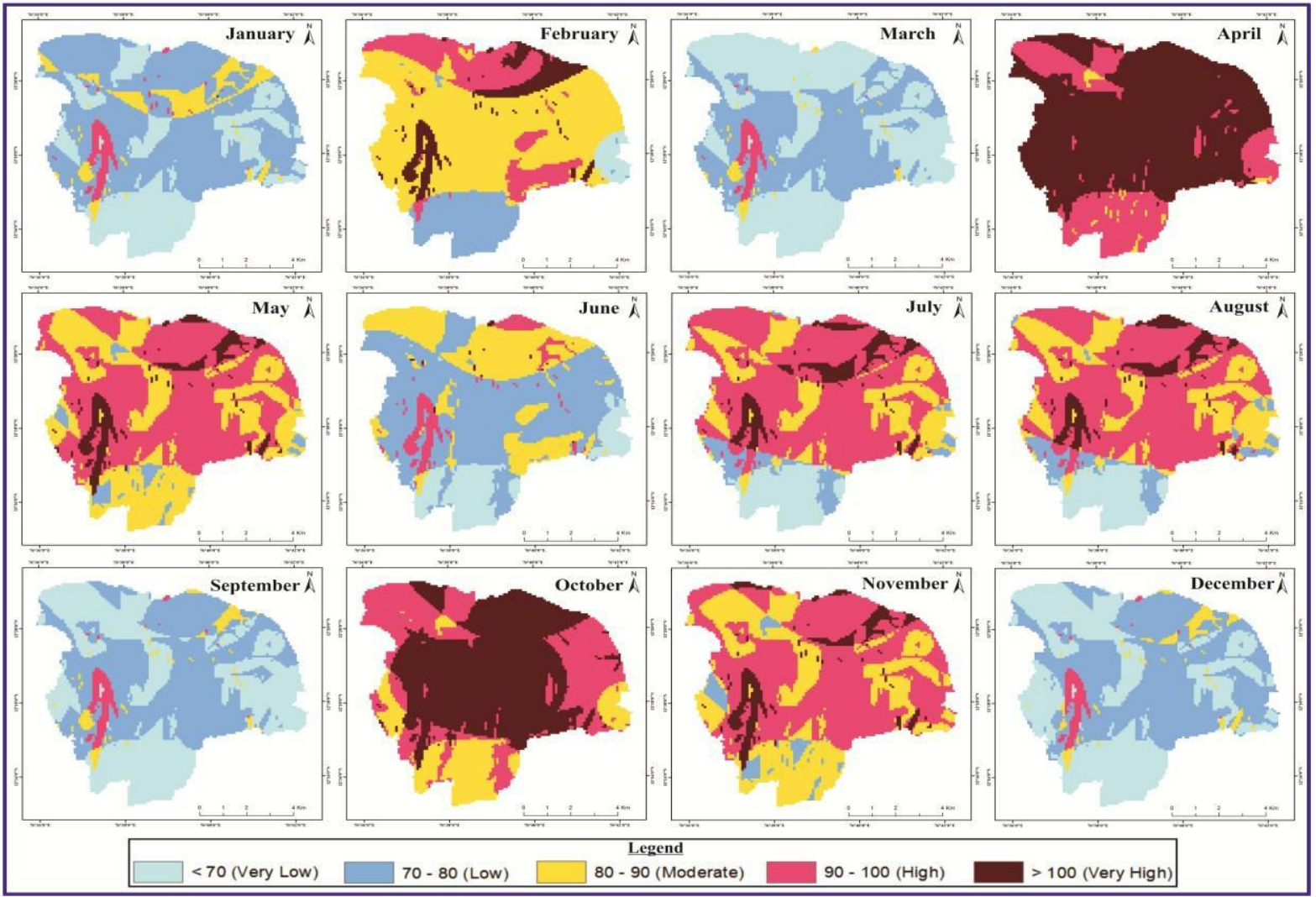

A Four Monthly Peer Reviewed Journal VISHWASHANTI MULTIPURPOSE SOCIETY (GLOBAL PEACE MULTIPURPOSE SOCIETY) 